\title{
SOUTH AFRICA's SUNDAY LAW: FINDING A COMPROMISE.
}

\author{
Jerry S. Ismail*
}

Western countries have traditionally prohibited or restricted a variety of activities from occurring on Sundays. ${ }^{1}$ This legislation is commonly referred to as "Sunday observance laws." Christians are the majority in such countries and many of them heed the biblical commandment to lay aside their work and observe the Christian Sabbath. ${ }^{2}$ Sunday laws, then, correlated with the spiritual convictions of much of the population. Until the beginning of the last century, this practice raised few concerns. ${ }^{3}$ Although there was some evidence that these laws were viewed as obstacles to commerce, there was little evidence of general opposition to them on religious grounds. ${ }^{4}$

As the number of nonbelievers and adherents of non-Christian faiths grew in these countries, the practice of Sunday observance laws underwent scrutiny for justification based on principles of religious freedom and neutrality. ${ }^{5}$ By then, an additional reason emerged to proscribe Sunday activity: to provide all people, regardless of faith, with a common day of rest. ${ }^{6}$ Societal forces largely having nothing to do with religion supported this move. Among the most influential of these forces was the labor movement, which was more concerned with working conditions and the Rights of Man than with religious ideology. ${ }^{7}$ Under such influences, the secular idea of the weekend began stealing into the original, religious rationale for the legislation.

As Sunday laws continue in a variety of forms today, the debate is centered not only on the original intent but the continuing purpose of the legislation. Often the State concedes its past association with religion but maintains that the current purpose of the laws provides health, safety, and

* J.D. Emory University School of Law, 1998; B.A., State University of New York, Albany, 1994 (honors). The author practices law in Atlanta, GA, where he also reports on legal issues as a freelance writer. The author wishes to thank Johan D. van der Vyver, I.T. Choen Professor of International Law and Human Rights at Emory University School of Law, for his support in this project, and to MKI for her constant encouragement.

1. See David N. Laband \& Deborah HendRy Heinbuch, Blue Laws: The History, ECONOMICS, AND POLTICS OF SUNDAY-CLOSING LAWS 139 (1987).

2. "Remember the sabbath day, to keep it holy. Six days shalt thou labour, and do all thy work. But the seventh day is the sabbath of the Lord thy God: in it thou shalt not do any work." Exodus 20:8-10, (King James).

3. See William addison Blakely ed., american State Papers and Related DOCUMENTS ON FREEDOM IN RELIGION 259 (4th ed. 1949).

4. But see id.

5. See, e.g., Barbara J. Redman, Sabbatarian Accommodation in the Supreme Court, 33

J. CHURCH \& ST. 495, 496-503 (1991).

6. See LABAND \& HEINBUCH, supra note 1.

7. See id. 
welfare benefits for the public. ${ }^{8}$ Other observers charge that Sunday laws have not abandoned their religious moorings and continue to be an impermissible combination of religious endorsement and infringement on freedom of belief. ${ }^{9}$

While these competing views at times seem irreconcilable, several approaches have been taken to lessen the overt religious impact of the laws. Over time, many of the main proscriptions have been omitted or decriminalized. ${ }^{10}$ Others have gone routinely unenforced. In favor of facilitating commerce, several American states have reduced fines imposed on merchants for selling goods on Sundays. Others have passed exemptions that allow non-majoritarian believers to work on Sundays. " In many instances, Sunday laws have withered on the vine and died out of their own accord. ${ }^{12}$ However, this is by no means representative of other jurisdictions, where the legislation is still alive and well. ${ }^{13}$

In spite of these attempts at reconciliation, the debate continues over the proper place for Sunday legislation. At stake for the majority is the potential loss of something so natural to its identity - a veritable tradition, that its absence would likely bring about a feeling of indignation. On the other side of the debate is the sentiment of those in the minority who view the continuation of Sunday laws as favoring a privileged class to which they do not belong. As a result of such laws, many of these individuals also suffer a loss of earning capacity if they observe Sabbath on another day of the week. To avoid either of these consequences, Sunday-law countries must find a compromise that supports the interests of both sides of the issue.

One country currently dealing with these competing interests is South Africa. This article analyzes the position of the sole remaining Sunday legislation in South Africa and compares and contrasts it with similar laws in the context of well-known American case law.

South Africa makes for a timely discussion for several reasons. Historically, South Africa has been a closed society - one that has not been open to democratic influences for all of its citizens. ${ }^{14}$ Consequently, Sunday laws largely represented the values of a political and social elite. Clear religious consideration buttressed the legislation. ${ }^{15}$ With the demise of apartheid, however, the veil of religious entanglement has begun to fall away. Courts now have the opportunity to judge the legislation of the old regime under principles of religious tolerance commonly observed in the West.

8. See id.

9. See BlakelY, supra note 3, at 379.

10. See Redman, supra note 5 , at 496.

11. See id. at 503.

12. See id. at 496.

13. See id.

14. See Johan D. van der Vyver, Religion, in THE LAW OF South AFRICA 198 (W.A. Joubert \& T.J. Scott eds., 1976); see also Johan D. van der Vyver, State-Sponsored Proselytization: A South African Experience 14 EMORY INT'L L. REV. 779, 781 (2000).

15. See van der Vyver, State-Sponsored Proselytization, supra note 14, at 783-85. 
South Africa is also a multi-confessional country, where controversies in church-state relations are likely to occur. ${ }^{16}$ Additionally, South Africa makes a good case study because its Constitution encourages the use of foreign precedent in controversies where individual liberties are at stake. ${ }^{17}$

The United States, as the comparison country, was chosen for reasons that have much to do with those cited for the case country. Like South Africa, the United States is a predominantly Christian country and has a considerable representation of religious minorities. ${ }^{18}$ The United States also has wellestablished legal precedent on this subject matter. ${ }^{19}$

These similarities aid in understanding the direction Sunday legislation and jurisprudence are taking in South Africa. A word of caution, however, is in order: The two countries are far from unified in their approach to analyzing issues of religious liberties; some of the thinking that underpins one country's opinions may not apply to that of the other. This will be evident in the sections of this paper dealing with the "establishment clause." Consequently, even parallel issues do not always result in precedent applicable to both legal systems.

The central focus of this article is the recent South African case, State $v$. Lawrence. ${ }^{20}$ At issue there was the constitutionality of South Africa's Liquor Act, which prohibited the sale of alcohol in grocery stores on Sunday. ${ }^{21}$ The discussion of South African Sunday laws commences with a brief overview of the legislation's history. Religious and secular justifications for its existence are offered. A Statement of the Case follows, providing the procedural and factual background of the main case under consideration. The paper then proceeds to explain and comment on the three opinions produced by the case. Finally, the paper closes with a summary of the main legal arguments and a conclusion as to the holdings in the case.

16. See The Land and its People, in SOUTH AFrICA YEARBOOK 1, 3 (Government Communication and Information System, Delien Burger ed., 2000) [hereinafter S.A. YEARBOoK $2000 / 01$ ], which quotes 1996 census figures of a population of 40.58 million people, $80 \%$ of . whom identify themselves as Christians, "with large Hindu, Muslim and Jewish minorities." Id. at (page number?) See also, Amanda Gouws \& Lourens M. du Plessis, The Relationship Between Political Tolerance and Religion: The Case of South Africa, 14 EMORY INT'LL. REV. 657, 668-75 (2000) for an insightful discussion and survey on the relationship between religion and tolerance for the "other" in South Africa.

17. See S. AFr. CONST. ch. 2, §39, "Interpretation of the Bill of Rights."

18. See STatistical ABstract of the UNITEd States: THE National Data Book 70 (quoting 1990 census figures).

19. See Lourens M. du Plessis, Religious Human Rights in South Africa, in REJuglous Human Rights in Global Perspective: Legal. Perspectives 441, 443 (Johan D. van der Vyver \& John Witte, Jr. eds., 1996), where the author states, "South Africa's common-law originated from Roman-Dutch law but has to a large extent been amplified - and in some areas transformed - by English law." Id.

20. This controversy is based on three different but related appeals: $S$ v. Lawrence; $S$ v. Negal; and S v. Solberg, 1997 (4) SA 1176, 1997 (10) BCLR 1348 (CC). The Constitutional Court (CC) is uniquely empowered to hear appeals of constitutional questions.

21. See Liquor Act 27 of 1989. 
This paper concludes that the Liquor Act does not violate the right to freedom of religion contained in the South African Constitution. The legislation is supported by a legitimate secular state interest, it is neutral on its face, and it is generally applied as such, the law is a valid limitation on a citizen's fundamental rights.

There is, however, a more serious question of whether the Act unfairly discriminates against individuals on the basis of religion, in contravention of Section 8 of the interim Constitution. ${ }^{22}$ This paper takes the position that the injury complained of need not palpably denigrate, nor exalt, one religion over the other to support a claim of unfair discrimination. It is sufficient that the relevant legislation radiate a clear message of association with believers of one faith over those of others, and that this results in some tangible disadvantage to the protesting party.

As the South African legislation radiates a clear preference for Christianity and unnecessarily places some non-Christians at a financial disadvantage, the Liquor Act is unfairly discriminatory. For reasons that are discussed below, this violation is not redeemed by the State's limitation power. Ultimately, such legislation cannot withstand critical scrutiny under the bedrock notions of the new South African society: An open and democratic society based on human dignity, equality and freedom.

To survive such scrutiny and avoid causing wounds to either side of the debate, the State must rewrite its Sunday legislation in such a way that association with any particular religion is excluded, or significantly reduced. Once this is done, both sides will in a sense prevail.

\section{HISTORICAL BACKGROUND OF SOUTH AFRICA'S SUNDAY LAWS}

South Africa has been described as a religious nation. Census figures indicate that an overwhelming majority of South Africans identify with a particular religion. ${ }^{23}$ Most claim membership in Christian churches, but there are also large Hindu, Muslim, and Jewish communities. ${ }^{24}$ To understand the crux of the debate over the purpose underlying Sunday laws today, however, one needs to become familiar with the prevailing religious worldview of the 17 th century Europeans who settled in southern Africa. ${ }^{25}$ These colonialists brought with them the Roman-Dutch legal system. That system was substantially informed by Catholic and Calvinist dogma, ${ }^{26}$ which converged

22. South Africa was ruled by a transitional constitution from 1993-1997, see INTER. CONST. (Act 200 of 1993) [hereinafter interim Constitution]. Chapter 3, Section 8 of the interim Constitution prohibited unfair discrimination by the government on the basis of, among other things, religion. See id.

23. See du Plessis, Religious Human Rights, supra note 19, at 442.

24. See S.A. YEARBOOK 2000/01, supra note 16.

25. See van der Vyver, State-Sponsored Proselytization, supra note 14, at 783.

26. See van der Vyver, Religion, supra note 14, at 177. 
in their advocacy that the State, as temporal sovereign, had a divine obligation to rule over its subjects according to principles established in biblical scripture. ${ }^{27}$

This imperative was accomplished by developing positive law that most nearly reflected a belief in divinely inspired law. ${ }^{28}$ The State, through the use of its sovereign powers, acted as God's trustee for the benefit of mankind. ${ }^{29}$ In this relationship, the line between church and state often became completely blurred. The Articles of Faith of the Calvinist church very clearly illustrate this. The State, in partnership with the church, was

[T]o watch over sacred Church services, to avert and stamp out all idolatry and false religions, to strike down the kingdom of the Antichrist and to promote the Kingdom of Jesus Christ, to permit the gospel to be preached everywhere in order that all would honor and serve God, as his Word commands us. ${ }^{30}$

In carrying out this mandate, the State historically intervened on behalf of the Church in several significant areas. Among these was its effort to compel the population to keep the Christian Sabbath. From 1652 until late into the twentieth century, the South African legislature drafted a number of proscriptions that made it difficult to do anything else on Sundays except observe the Sabbath. These measures included the prohibition of buying goods, working at one's job, hunting, fishing, gardening, and traveling, except to and from services. ${ }^{31}$ Many, if not all of these laws, have been repealed or amended. ${ }^{32}$ But as one observer familiar with South Africa stated, "The formative years of South African law included a period when religious forces had a definite influence on legal institutions. ${ }^{33}$ Moreover, when the State did side with a religion, it always sided with the Christian religion. ${ }^{34}$

Observance laws were not the only area where the State acted as the handmaiden of Christianity. Without regard to religious belief, witnesses in criminal trials were required to swear out an oath adopted for use solely by

27. See id.

28. See id.

29. See id. The combined Roman-Dutch worldview proposed a transformation of Mosaic Law and the Decalogue into proscriptions of positive legal affirmations. See id.

30. Id. at 178.

31. See id. at 198-200.

32. See van der Vyver, State-Sponsored Proselytization, supra note 14, at $788-90$, for examples of how the white-led apartheid government used security measures to repress certain religious organizations, which also furthered its racial policies well into the late $20^{\text {th }}$ Century.

33. van der Vyver, Religion, supra note 14, at 176.

34. See id. at 198. 
Christians. ${ }^{35}$ Witnesses in civil proceedings, on the other hand, were permitted to make the affirmation that most effectively bound their consciences. ${ }^{36}$ This approach had the effect of elevating the Christian concept of God over that of others by combining it with the weightier matters of criminal justice and the State. ${ }^{37}$

Another example that illustrates the close association between church and state comes in the form of South Africa's now-defunct ${ }^{38}$ blasphemy statute. Under that law, it was a crime to slander only the God of Christianity. ${ }^{39}$ Other examples of the comingling of church and state included language used in the preamble of the 1961 Constitution which suggested that God had trinitarian overtones and indicated a special relationship between God and South Africa's European Christians. ${ }^{40}$

Alternative justifications for South Africa's Sunday legislation have been offered. Some commentators have noted that the practice of reserving Sundays for special prohibitions originated with the Emperor Constantine who, at the time, was identified with the pagan religion. ${ }^{1}$ Other commentators, recognizing the practice's Christian characteristics, if not origin, have argued that the legislation was never ensconced in a constitutional framework but remained solely statutory in nature. ${ }^{42}$ Proponents of this view maintain this distinction relegated the laws to a mundane status, one that never had much support, and generally went unenforced. Over time, it is said, these laws developed a certain civil quality that made them more ceremonial than consequential. ${ }^{43}$ 784.

35. See id. See also van der Vyver, State-Sponsored Proselytization, supra note 14, at

36. See van der Vyver, Religion, supra note 14, at 198.

37. See id.

38. But see Nicholas Smith. The Crime of Blasphemy and the Protection of Fundamental Rights, 116 S. AFR. L.J. 162, 172-73 (1999), where the author raises the possibility that the offense of blasphemy, which is no longer a crime, could still be punished if a statement containing blasphemous content were held to violate the constitutional prohibition of incitement to hatred or violence based on religion. See S. AFR. CONST. ch. $2, \$ 16$.

39. See van der Vyver, Religion, supra note 14, at 199-200; and see State-Sponsored Proselytization, supra note 14, at 785.

40. See van der Vyver, Religion, supra note 14, at 9; State-Sponsored Proselytization, supra note 14, at 787, where the author states that when read in the original Afrikaans, the constitutional confession of faith, "die volk van ... Suid-Afrika," has clear ethnic and religious implications. See id.

41. See van der Vyver, Religion, supra note 14.

42. See id. at 149. But see Jeremy Sarkin, The Political Role of the South African Constitutional Court, 114 S. AFR L.J. 134 (1997), noting that prior to the introduction of a supreme constitution in 1994 that established an independent judiciary, South Africa was ruled by a system that placed supremacy in the power of the legislature and gave only limited powers to the courts to interpret and apply the law within very narrow bounds. There was thus no effective check on legislative power, relegating judges to the status of "mere technicians" in the pursuit of justice. See id.

43. See van der Vyver, Religion, supra note 14. 
Additional arguments have been put forth in support of an entirely secular purpose for the laws. The most common justification cited under this class is that of a national day of rest for all. ${ }^{44}$ In this age of seemingly endless bustle and commerce, the argument is made, the State has decided to provide one day a week during which everyone, regardless of religious affiliation, can rest, enjoy recreation, spend time with family, or engage in reflection. This national day of rest, it is maintained, is meant to improve both the health of the individual and the welfare of the nation. ${ }^{45}$

Even more particularized health-related purposes for the legislation have been offered. For instance, the State maintains that the reason for Sundayclosing laws is to protect the people from harms resulting from alcohol and alcohol-related mishaps. ${ }^{46}$ While this may be a concern of the State, critics argue that it is not likely to be the sole, or even the central justification for the legislation's existence. Detractors from this point of view note that the current South African Sunday law prohibits sales of alcohol only on Sundays and certain Christian holy days. ${ }^{47}$ This juxtaposition seems to taint the law's secular credentials, especially as alcohol sales are not prohibited on other public holidays.

In sum, South Africa's Sunday laws have historically been connected to Christianity and the Christian Sabbath. There are also secular reasons for their existence. The critical question today is how much of the original intent of the laws remains in place and, equally, how much of the original effect survives. The case that follows was the first attempt to answer these questions in a postapartheid legal setting. Above all else, the Constitutional Court engaged these questions against the backdrop of a new South African Society based on "democratic values, social justice and fundamental human rights."48

\section{STATEMENT OF THE CASE}

The factual background of State $v$. Lawrence is relatively simple. Three South African citizens were charged with violating the Liquor Act 27 of 1989 ("the Liquor Act", "the Act"), which in relevant part prohibited the sale of alcoholic beverages by grocers on Sundays. ${ }^{49}$ Appellants all worked for a large corporation that operated an international chain of convenience stores. None of the appellants contested the factual charges brought by the State, and

44. See id. at 47.

45. See S v. Solberg, 1997 (10) BCLR 1348 (CC), T 53, 95-97.

46. See id. $9170,175$.

47. See id. 1159.

48. See S.A. Yearbook 2000/01, supra note 16, at 67.

49. See Liquor Act 27 of $1989 \$ \$ 88-90$. In basic terms, these sections prohibited the sale of alcohol other than table wine by grocers who held wine licenses. See id. $\$ 88.1$. The law also restricted the hours of the sale of alcohol to 8 p.m. during the week and 5 p.m. On Saturday. See id. $\$ 90.1$. Most relevant to this discussion is the prohibition of wine sales on Sundays. See id. 
each was convicted in the magistrate's court. On appeal, appellants argued that the Act violated the Constitution on two grounds. First, they maintained, the Act violated Section 26 of the interim Constitution. ${ }^{50}$ That Section guaranteed to all South Africans the right to engage in economic activity. ${ }^{51}$ Appellants offered an expansive interpretation of this clause, suggesting that it supported their capacity to engage in any economic enterprise they chose, except "innately criminal" activity without being subject to government regulation. ${ }^{52}$ The Court dispatched [word choice?] this part of appellants' argument. ${ }^{53}$

Second, appellants maintained that the Act violated Section 14, which, among other things, guaranteed freedom of religion. ${ }^{54}$ Of the appellants, Ms. Solberg's appeal most directly hinged on Section 14, and it is her appeal that is the subject of much of the Court's decision. Section 14 of the interim Constitution states in part: "(1) Every person shall have the right to freedom of conscience, religion, thought, belief and opinion, which shall include academic freedom in institutions of higher learning."

In the main, Ms. Solberg argued that the Liquor Act, by constraining the days on which she could sell alcohol, forced her to observe the Christian Sabbath in violation of Section 14. ${ }^{36}$ Appellant argued that even indirect official recognition of one religion's Sabbath over others implies State endorsement. ${ }^{57}$ Appellant further maintained that the imposition of Sunday closed-days violated her right to freely exercise the faith of her choice. ${ }^{58}$ As such, appellant raised both freedom of religion and establishment challenges to the law.

The State responded that the Act was decreed for secular purposes, namely to reduce the destructive consequences of drinking alcohol and to promote health and recreation on the one day of the week when most South Africans were off from work. ${ }^{59}$ The State, however, provided no answer to the allegation that the Act was tainted by the choice of other, clearly religious closed-days. ${ }^{60}$

50. See S v. Solberg, 1997 (10) BCLR 1348 (CC), II 7, 83. Except where noted, the substance of the interim Constitution is much the same as the final draft in place today.

51. See id. 97. Section 26(1) of the interim Constitution stated "Every person shall have the right freely to engage in economic activity and to pursue a livelihood anywhere in the national territory." Id. \ 26. Section 26 was omitted from the final draft of the permanent Constitution.

52. See id. 927.

53. See id. $\mathbf{9} 29$.

54. See id. $917,83$.

55. Id. 984 . Section 14 is Section 15 in the current Constitution.

56. See id. 985.

57. See id. $\mathbf{9} 86$.

58. See id. 985.

59. See id. II 53-54, 95-96, 115.

60. See id. II 86-87. 
Ultimately, six of the nine justices hearing the case agreed with the State's position and rejected appellant's arguments, holding that South Africa's Liquor Act does not violate an individual's right to freedom of religion under Section 14. The Justices, however, split into three factions: the plurality, led by the President of the Court, Justice Chaskalson; a concurrence, led by Justice Sachs; and a dissent led by Justice O'Regan. ${ }^{61}$ The opinions varied greatly ${ }^{62}$ on whether the South African Constitution contained an "establishment clause;" and if it did, whether the Act was violative of that measure.

\section{LEGAL ANALYSIS}

\section{A. The Plurality Holding \\ 1. Equality and Establishment}

According to the plurality opinion, there is no establishment clause of any kind in the South African Constitution. ${ }^{63}$ Appellant argued that if Section 14 did not contain an explicit establishment clause, one was either implied or could be constructed by importing language from other sections of the Constitution. Specifically, appellant argued that when read together, Sections $14(1)$ and 14(2), created the functional equivalent of an establishment clause. ${ }^{64}$ Section 14(2), states: "Without derogating from the generality of subsection (1), religious observances may be conducted at state or state-aided institutions under the rules established by an appropriate authority for that purpose, provided such religious observances are conducted on an equitable basis and attendance at them is free and voluntary.

61. The judgment of the Court included President of the Court, Chaskalson, Langa D.P., Ackermann, J. and Kriegler. J. (That is, four justices.) The concurring opinion was supported by Sachs and Mokgoro, JJ. The dissent consisted of O'Regan, Goldstone and Madala, JJ. See generally S v. Solberg, 1997 (10) BCLR 1348 (CC).

62. See A.J.H. Henderson, Note, Diversity of Opinion in a Diverse Society, 61 TYDSKRIF VIR HEDENDAAGSE ROMENSS-HOLANDSE REG 348, $351-54$ (1999), where the author states that the splintered Court revealed stark philosophical differences in constitutional interpretation, with Chaskalson, P., adopting a narrow, statute-like reading of the Constitution in order to resolve the controversy without unnecessarily opening up the Constitution to the imprint of foreign jurisprudence; and Justices Sachs and O' Regan, former academics, generously relying on American establishment clause decisions to support their theses. See id. According to Henderson, Sachs' and O'Regan's approach reflected a "substantive vision of the law" as a direct reaction to the formal approach that characterized much of Apartheid South African jurisprudence. See supra note 42. Henderson maintains, however, that this approach itself is problematic. See id.

63. See infra note 74, for text of the American "establishment clause." See S v. Solberg, 1997 (10) BCLR 1348 (CC), II 100-01.

64. See S v. Solberg, 1997 (10) BCLR 1348 (CC), I 103.

65. Id. $\ 84$. 
In declining to adopt appellant's view of a synthesized establishment clause, the plurality held that "equitable basis" was not equivalent to lock-step equality or nonpreference in religion. Rather, it is synonymous with the promotion or inhibition of religion in a "fair and appropriate manner." Thus, in situations of prayer in public schools, the Court said, Section 14(2) does not require that accommodation be made for every denomination present at the school. ${ }^{67}$ What is required is that school officials give due consideration to the diversity of the demographic population in the institution. Additionally, officials must provide safeguards to protect nonbelievers from being coerced into another's religious observance. ${ }^{68}$

Based on the plurality opinion, it is clear that the South African Constitution envisioned an intertwining relationship between religion and State. ${ }^{69}$ According to the holding, the fact that one religion was favored in certain situations did not, in and of itself, support a violation of Section 14(2). To establish such a claim, appellant was required to show that the favoritism took place at a state institution, that the favoritism was inequitable, or that she was in some way coerced into participating. ${ }^{70}$

In support of her claim that the Liquor Act reflected inequitable favoritism, appellant produced evidence showing that the only closed-days chosen in the Liquor Act's legislative history were days of Christian significance: Christmas Day, Good Friday, Ascension Day, and Sunday. ${ }^{71}$ In appellant's view, this laid the foundation for the fundamental religious purpose of the Act. However, it was difficult, if not impossible, for appellant to maintain that Sundays were a "state institution" or that she was coerced into taking part in a religious ceremony. Thus, the Court held that Section 14(2) did not provide appellant with relief. ${ }^{72}$

According to the plurality, Section 14 does not envision a high wall separating church and state. ${ }^{73}$ This contrasts with the American view where the historical model has been separation of church and state. ${ }^{74}$ An example of how the two systems differ is exemplified by looking at how the courts analyze the issue of reading scripture in public schools. In Abington Township School District v. Schempp, the United States Supreme Court held that

66. Id. 9103.

67. See id.

68. See id.

69. See van der Vyver, State-Sponsored Proselytization, supra note 14, at 824.

70. See S v. Solberg, 1997 (10) BCLR 1348 (CC), 9104.

71. See id. 986.

72. See id. 105.

73. See id. $19101-04$.

74. See id.; U.S. CONST. amend. I states "Congress shall make no law respecting an establishment of religion, or prohibiting the free exercise thereof...." Id. See also, 8 Works of Thomas Jefferson 113, where the Founding Father stated, "I contemplate with sovereign reverence that act of the whole American people which declared that their legislature should 'make no law respecting an establishment of religion, or prohibiting the free exercise thereof,' thus building a wall of separation between church and State." Id. 
religious readings at a public school function were unconstitutional. ${ }^{75}$ In its view, the test was that the practice put the power and authority of the State behind an activity associated with a particular religion; in doing so, it created the impression of an officially-endorsed religion. ${ }^{76}$

It is difficult to imagine that such religious readings would violate Section 14 of the South African Constitution. So long as "fair and appropriate" safeguards achieved an "even-handed" approach among different faiths, religious readings would be permitted under South Africa's Constitution. $^{n}$

However, the Court did acknowledge an "equality provision" in Section 8 of the interim Constitution, which provided relief for individuals complaining of unequal treatment in, among other things, religion. ${ }^{78}$ Section 8 states in part that "(1)Everyone is equal before the law and has the right to equal protection and benefit of the law. (3)The State may not unfairly discriminate directly or indirectly against anyone on ... [the basis of] religion." 79

The Plurality held that although Section 8 does not amount to an establishment clause, it does provide similar protections. ${ }^{80}$ By its very terms, Section 8 prohibits even "indirect" discrimination. Unfortunately, the Constitutional Court declined to evaluate the case under Section 8 , as that section was not briefed by appellant. ${ }^{81}$ Moreover, the plurality rejected appellant's approach of incorporating the anti-discrimination provisions of Section 8 into Section 14 which, after Section 26, was the only section relied on by appellant in her appeal. The Court maintained that adopting appellant's approach would give rise to "any number of problems not only in relation to freedom of religion but also in relation to freedom of conscience, thought, belief and opinion, which would go far beyond the difficulties raised by the 'establishment clause' of the United States Constitution." 82

In analyzing the South African Constitution for evidence of an establishment clause, the plurality correctly concluded that one does not exist. ${ }^{83}$ Indeed, it is difficult to reconcile the language of the Constitution,

75. See School District of Abington Township, Pennsylvania, et. al. v. Schempp et. al., 374 U.S. 203, 205 (1963).

76. See id. at 223-25.

77. See Gouws \& du Plessis, supra note 16 , at 683 . The formula provided by the plurality seems to invite the conclusion that any accommodation of religion in public life will be permissible so long as the relationship passes the very subjective criteria embodied in $S .14(2)$.

78. See S v. Solberg, 1997 (10) BCLR 1348 (CC), 102 . The other factors include race, gender, pregnancy, ethnic or social origin, color, sexual orientation, age, disability, culture, language and birth. See id.

79. S. AFr. CONST. ch. $2, \S 9$. Section 8 of the interim Constitution is Section 9 in the final draft.

80. See S v. Solberg, 1997 (10) BCLR 1348 (CC), I 100.

81. See id. 1102.

82. Id.

83. See van der Vyver, State-Sponsored Proselytization, supra note 14, at 823-24. 
especially Section 14(2), with the American notion of non-establishment. As Section 14(2) expressly allows for religious observances at state institutions so long as they are free, voluntary, and conducted on an equitable basis. Official support of religion is undoubtedly permissible so long as such a relationship meets that criteria.

The plurality, however, having gone so far toward admitting Section 8 as the proper grounds for evaluating allegations of unequal treatment allowed an oversight in the pleadings to forestall a firm resolution of this issue. This is a tough approach, and one certainly open to criticism. However, the Court has signaled to litigants that Section 8 is to be considered in future controversies involving religious discrimination.

\section{Freedom of Religion}

Appellant argued that prohibiting her from selling alcohol on a Sunday violated her constitutional right to pursue the faith of her choice, as the law interfered with her ability to take another day off from work to worship without suffering a monetary loss. To demonstrate the impact of Sunday legislation on non-Christian sabbatarians, appellant argued that the South African law was similar to the law implicated in the Canadian case, Regina $v$. Big M Drug Mart, $L t d .^{84}$ In that case, the Canadian High Court pronounced the Lord's Day Act unconstitutional. ${ }^{85}$ The Act prohibited a wide range of common activity from occurring on Sundays, including all labor and commerce, fee-based recreation, and the sale and distribution of foreign newspapers. ${ }^{86}$. The High Court, in striking down the law, held that the legislation had no neutral purpose and was solely meant to "compel observance of the Christian Sabbath."

The South African Court agreed that the Canadian Act plainly violated freedom of religion and transgressed establishment principles, as well. ${ }^{88}$ However, the plurality opinion drew a sharp distinction between the two Acts. While the Canadian Act prohibited engaging in any activities on Sunday other than observing the Christian Sabbath, the South African Act solely restricted the day, time, and type of alcohol that a grocer could sell. ${ }^{89}$ It did not prohibit grocers generally from selling products on Sundays. It did not require anyone to open or close his store on Sundays. It did not entirely prohibit the sale of

84. Regina v. Big M Drug Mart, Ltd. (1985) 13 CRR 64.

85. See S v. Solberg, 1997 (10) BCLR 1348 (CC), 9 87-90 (quoting Regina v. Big M Drug Mart, Lid. [1985] 13 CRR at 93).

86. See id. 988.

87. Id. 192.

88. See id. I 90. Regarding establishment principles, the plurality was reflecting on the Canadian situation.

89. See id. 
alcohol on Sundays. ${ }^{90}$ Moreover, according to the plurality, the Act did not prevent grocers in any way from exercising their religious convictions. They were free to observe the Sabbath on Friday, Saturday, Sunday, or any other day of the week. In essence, what was lacking from the South African Act was coercion. Short of a Canadian-styled Act, "the selection of a Sunday for purposes which are not purely religious in nature and do not constrain the practice of other religions would [not] be unlawful simply because Sunday is the Christian Sabbath."9!

In so holding, the Court adopted reasoning similar to that announced by the United States Supreme Court in Braunfeld $v$. Brown. ${ }^{\text {22 }}$ In that case, Orthodox Jewish merchants from Philadelphia challenged Pennsylvania's legislation, that closed shops on Sunday on the grounds that the law violated their right to freely follow the faith of their choice as guaranteed in the First Amendment. ${ }^{93}$ Appellants argued that the law penalized them solely because they practiced a faith other than Christianity. ${ }^{94}$ Appellant maintained that closing for an additional day cost the merchants a considerable amount of business solely, in their view, because they were Jewish. This amounted to an involuntary choice between a central tenet of appellants' faith and their livelihoods. ${ }^{95}$

In upholding the constitutional validity of the law, the plurality centered its ruling on the distinction between beliefs and opinions on the one side, and action on the other. ${ }^{96}$ The right to hold the former is absolute; the latter, it held, is susceptible to restriction when it is "in violation of important social duties or subversive of good order, even when the actions are demanded by one's religion." 97

The conduct in question was not demanded by appellants' religion; it was one step removed. That is, it was activity incidental to appellants' religion. The law simply made it more difficult for appellants to practice their faith; it did not prohibit them from doing so, and in no way enjoined them from following the tenets of their faith. ${ }^{98}$ The law, thus, imposed only an indirect burden on appellants.

As the number of indirect burdens is nearly limitless, the Court was persuaded to adopt the view that these burdens were presumptively valid because holding otherwise would "radically restrict the operating latitude of

90. See id. TI 90, 94. Restaurant establishments, for instance, were permitted to sell alcohol under the law, so long as it was consumed on premises. See id. I 90.

91. Id. 989.

92. See Braunfeld v. Brown, 366 U.S. 599 (1961).

93. See id. at 602.

94. See id. at 601.

95. See id. at 602.

96. See id. at 603-04.

97. Id.

98. See id. at 605-06. 
the legislature."99 The plurality held, however, that not all indirect burdens would be overlooked, even under a rational basis review. Where the purpose or effect of the legislation is to impede or discriminate against religion, the law is invalid even if the burden is slight. ${ }^{100}$ Where, however, the law is neutral on its face, is generally applied, and has a secular purpose, then the legislature will not be bound. ${ }^{101}$

Similarly, the plurality held that the Liquor Act did not violate the Constitution, as the law was neutral on its face, generally applied, and had a legitimate secular purpose. The fact that the law may have once had religious foundations, it held, was not fatal to this outcome. ${ }^{102}$ So long as the religious origins of the statute in question existed alongside economic and social justifications for the law, its origins were not dispositive. ${ }^{103}$

Further, the plurality opined that had the Act demonstrated an interference with appellant's freedom of religion, such interference might be permissible under the State's constitutionally-provided limitation powers. ${ }^{104}$ The Court avoided making this decision, however, thereby leaving open the possibility that something more than a "reasonable limitation" but less than an all-out prohibition on Sunday activity, as envisioned by the Canadian Act, could tip the scale toward an impermissible violation of the right to freedom of religion. ${ }^{105}$ The plurality simply did not find that the facts in this case warranted such an examination.

Appellant's case suffered from two major defects. First, it is clear that appellant was not a religious victim of the Act. She - and more to the point, her employer - were adversely affected economically by the law. ${ }^{106}$ The law made it somewhat harder for them to make a profit on Sundays. On this point, it is important to note that appellant's religious convictions are completely absent in the judicial record. Although the Court readily admitted appellant's right to bring a claim challenging a statute under religious liberty, the language

99. Id. at 606 .

100. See id. at 607.

101. See id.

102. See S v. Solberg, 1997(10) BCLR 1348 (CC), 99 89, 156. See also McGowan v. Maryland, 366 U.S. 420, 426, 434 (1961).

103. See S v. Solberg, 1997 (10) BCLR 1348 (CC), TI 89, 156.

104. See id. 998 . Under $\$ 33$, the legislature could limit fundamental individual rights so long as the limitation is "reasonable, justifiable, and necessary." "Necessary" was removed from the final draft.

105. See id. I 93, where the President of the Court remarked that he is not "unmindful of the fact that constraints on the exercise of freedom of religion can be imposed in subtle ways." ld.

106. See id. 97. See also Michele Havenga, Corporations and the Right to Equality, 62 TYDSKRIF VIR HEDENDAAGSE ROMEINS-HOLANDSE REG 495, 497 n. 10 (1999), where the author makes the argument that had the corporation been charged instead of its employees, it should have been able to avail itself of the same defenses used by appellants, namely that the Act violated its "Freedom of Religion." Id. 
of the decision suggests that her economic motives had much to do with the outcome of the case. ${ }^{107}$

The Court dealt with this case in a near-total religious vacuum. ${ }^{108}$ There were no briefs filed with the Court by religious organizations, and there was a dearth of evidence in the record on the financial impact to non-majoritarian believers subject to the Act. In the absence of an establishment clause, it proved very problematic for a non-religious defendant to prevail against a general law by utilizing mostly free exercise arguments.

The second deficiency in appellant's case is based on her reliance on the Canadian case. In arguing that the two Acts were similar, appellant's case was weakened from the inside. The effect of the South African law paled in comparison to the sheer coercion present in the Canadian Act. As such, appellant's choice gave the Court a radical benchmark against which to judge the South African law. The result was that the Liquor Act appeared less harmful to religious sensitivities than otherwise might have been the case. This outcome might have been avoided had appellant focused on a stronger choice of cases or a passionate appeal to the disparate impact on nonbelievers occasioned solely by their convictions.

\section{B. The Concurring Opinion}

In a separate opinion, two justices concurred with the plurality. Their opinion dealt solely with the Solberg appeal. The justices posed the question: Does the prohibition of wine sales by grocers on Sundays violate appellant's religious rights? ?09 $^{10}$ They found two instances where the Act might do so under Section 14: a disparate impact on non-Christians solely occasioned by their choice of belief systems; and the appearance of a favored religion. " Essentially, the first instance is a question of freedom of religion; the second is a question of establishment.

\section{Freedom of Religion}

The notion of disparate impact was difficult for the concurring justices to escape, especially when they considered the realities of the grocer's trade. In competing with one another, shopkeepers seek as many advantages over their competitors as they can in order to gain the public's business. A law that

107. See S v. Solberg, 1997 (10) BCLR 1348 (CC), I 140; see also id. I 8, where the Court notes that the only group that entered an appearance on behalf of appellant as an amicus curiae was the South African Liquor Store Association! See id.

108. See Gouws \& du Plessis, supra note 16 , at 681 , where it is noted that the absence of legal briefs from faith-based organizations helped ensure that this case was evaluated as one of commercial and not religious importance.

109. See S v. Solberg, 1997 (10) BCLR 1348 (CC), 9138.

110. See id. 19 137-38. 
mandates closed days may amount to such an advantage. ${ }^{111}$ In its barest form, the issue faced by the concurrence was reduced to this: If a non-Christian grocer observes sabbath on any other day than Sunday, all other things being equal, he is at twice the disadvantage of his Christian competitor, at least in terms of business resulting from the sale of alcohol. While the Christian grocer has the potential to sell alcohol six out of seven days, the non-Christian has the potential for only five. ${ }^{112}$ In the words of the concurring Justices, the Sabbatarian shopkeeper is "subjected to an invidious choice between following her religion or pursuing her trade."113

However, given the lack of evidence in the record supporting the Act's impact on appellant's religious freedom, the concurrence concluded that appellant did not suffer anything more than a slight economic disadvantage as a result of the Act. ${ }^{14}$ As in Braunfeld, the law had a legitimate purpose, was neutral on its face, and was generally applied to all concerned. Therefore, while recognizing the law's unequal effect on appellant, as compared to professed Christians, the effect amounted to no more than an "incidental burden."

The concurring Justices avoided viewing the constitutionality of Section 14 in a wider context. Although often stating that appellant had the right to challenge the Act whatever her motives, the concurrence seemed singularly focused on appellant's lack of religious credentials. This focus made it difficult for it to conclude that the purpose or effect of the Act was to inhibit non-Christian belief. ${ }^{115}$ That the Act might have adversely affected many other individuals who were subject to the impact of the law in all its manifestations was only considered as an afterthought.

In essence, the concurrence maintained that appellant's case was built not so much on a religious liberty foundation but on an economic freedom model. As the Court unanimously disagreed with that part of appellant's case, she was left to make religious arguments for why her conviction should be overturned. The concurring opinion reflected and, in some ways, exacerbated this imperfect approach.

\section{Establishment}

The concurring justices took for granted that which occupied much of the plurality's evaluation of the Constitution, namely, that Section 14 contains

111. See id. 9155.

112. See id. 1154.

113. Id.

114. See id. 9 154-55. But see id. 9 158, where it appears that Justice Sachs would not have reached a different conclusion had appellant been a true religious casualty of the Act.

115. In support of this position, the concurrence pointed out that South Africa's Sunday law regime has been eradicated, leaving the Liquor Act as the sole Sunday prohibition law in the country. See id. M1 149-51. However, the concurrence did not venture a reason why this Act, which had clear religious motivations, should have survived in its present form. 
an establishment clause. ${ }^{116}$ In the concurrence's view, it was not necessary to show that there was coercion at State-funded religious observances or official imposition of the Christian Sabbath to make out an establishment violation. Rather, what was required was a showing that there was an intertwining relationship between church and State, and that the comingling was impermissible under the State's limitation power. ${ }^{17}$ The justices concluded that such an entanglement existed because religious symbolism was inherent in all the Liquor Act's closed-days:

"[A]lthough part of the objective might have been purely secular, the means used, namely the selection of religiouslybased days as closed days, was intended to acknowledge and comply with the sentiments of those Christians who regarded these days as days requiring special observance."118

The Act, the concurrence opined, would not have been suspect on this basis had the list of closed-days included other, non-religious days, such as public holidays, which would have neutralized the religious effect of the Act. ${ }^{11}$ The plurality stated that evidence of the close relationship between religious holidays and closed-days showed that Christians were still viewed with favor. ${ }^{120}$ Accordingly, the appellant established that there was a facially inappropriate endorsement of religion. ${ }^{121}$

With this established the concurrence had to evaluate the endorsement under the State's Section 33 limitation powers. ${ }^{122}$ To be permissible, the limitation was required to be slight, "reasonable, justifiable and necessary."123 In applying this formula, the concurrence accepted that when the State adopts the habits of a particular religion, even for non-religious reasons, it gives the impression to the public that it prefers that religion. ${ }^{124}$

However, the concurrence maintained, this favoritism must be weighed against the State's objectives. In doing so, the justices contrasted the Liquor Act with Canada's Lord's Day Act. The Canadian law, it stated, was clearly

116. See S v. Solberg, 1997 (10) BCLR 1348 (CC), 14 141-48. While offering a multitude of textual references to support this point of view, it is a conclusion lacking in substance and analysis. See id.; see also van der Vyver, State-Sponsored Proselytization, supra note 14, at 827.

117. See S v. Solberg, 1997 (10) BCLR 1348 (CC), 9 158-60.

118. Id. 9159.

119. See id.

120. See id. 91 160, 163.

121. See id. 9164.

122. See id. 165 .

123. Id. The concurring justices interpret "necessary" as "not [being] made the subject of rigid definition, but rather regarded as implying a series of interrelated elements in which central place [is] given to... the means used to achieve a pressing and legitimate public purpose." Id. at n.152. The term was removed from the final draft.

124. See id. $\mathbf{I} 170$. 
intended to compel Sunday observance and no legitimate state interest could be found to support the Act. Conversely, the concurrence held, the Liquor Act was part of a health, safety, and welfare regime that did not seek to generally control what people did on Sundays. ${ }^{125}$ The effect of the law simply limited the sale of alcohol to the public on Sunday. At worst, the concurrence maintained, the Act led to a case of indifferent favoritism. ${ }^{126}$ Furthermore, the justices were of the opinion that the religious closed-days were not purely religious anymore. ${ }^{127}$

Applying a rational basis review, the justices concluded that the State's objectives were legitimate. ${ }^{128}$ The law was drafted, in their opinion, to prohibit the sale of alcohol on Sundays at grocery stores - not to close down shops or ban alcohol consumption entirely. As such, it was restricted in scope, the intrusion on appellant's religious rights was slight, and the means were reasonably related to that end. The remaining question was whether the means used to achieve the end were "necessary."

The final draft of the South African Constitution deleted "necessary" from the limitation clause, in part because of the difficulty in defining the term. ${ }^{129}$ However, since the prosecutions in this case occurred when the interim Constitution was in force, the Act must satisfy that requirement among others. Assuming "necessary" means "required," in the sense that no less restrictive means were available to bring about the stated ends, the terms of the Act arguably were not necessary.

At the time of appellant's violation, South Africa had twelve public holidays, only two of which were designated closed-days: Christmas Day and Good Friday. These days were the only patently religious days of the twelve. ${ }^{130}$ Their inclusion called into question the motivation behind the Act and made the addition of Sunday appear dubious. When Sundays are counted, the total number of closed-days amounts to, at most, fifty-four days per year. The concurring justices concluded that the inclusion of these days were "necessary" to bring about the State's objective, namely, tranquility and a reduction in alcohol abuse by the public. ${ }^{131}$

Two other approaches, however, appear to be as effective as that approved by the concurrence, while at the same time significantly reducing the suggestion of an endorsement of Christianity. The first restricts alcohol sales to Sundays only; it would remove Christmas Day and Good Friday from the

125. See id. TI 174-77.

126. See id. $\mathbf{I} 172$.

127. See id. $\mathbf{9} 173$.

128. See id. 175 . The concurrence pronounced the State's health and welfare argument to be "powerful and legitimate." Id.

129. See id.

130. See id. 1125.

131. See id. 
list of closed-days. ${ }^{132}$ Since the Court upheld as legitimate the need for the State to set aside a day of rest for the benefit of all its citizens, Sunday arguably makes the most sense based on prevailing social structure, current practice, and tradition. Removing the holy days would leave a statute in effect that has far less religious association and more secular purpose, without tangibly diminishing the effectiveness of the Act.

The second approach would add to the current closed-days all other South African public holidays, such as New Year's Day, Human Rights Day, and Family Day. ${ }^{133}$ While this actually increases the number of closed-days by about ten per year, it also strengthens the health, safety, and welfare thrust of the Act. These additions would also make the Act appear more secular by reducing the transparent associations with religion presently in the law.

The concurrence stated that it could not engage in speculation about the efficacy of the means used by the State to implement its laws. ${ }^{134}$ While this is true in cases of a prima facie review of a statute, that was not the situation presented to the Court. Once the Court determined that there was an infringement, it was obligated to inquire into the merits of the means used by the legislation. ${ }^{135}$ Based on the concurrence's own findings that a constitutional infringement had occurred, it was required to determine if less restrictive means were available. As the two examples above illustrate, there are less restrictive means available for use that would accomplish the State's goal while reducing or eliminating the infringement on religious liberty. Adopting either of these approaches would signal to nonmajoritarian believers that the government sees them as equal citizens.

\section{The Dissent}

Three justices dissented from the Court's decision. They agreed with the plurality that there is no establishment clause in the Constitution, yet the dissent ultimately found establishment clause protections implicit in the language of Section 14. ${ }^{136}$ Like the approach used by the concurrence, this was accomplished by incorporating provisions from other constitutional sections into a "contextual reading" of Section 14. In the dissent's view, since official participation in religious observances is permitted under the Constitution, there must exist some limited establishment clause inherent in Section 14 to ensure faimess in this process. ${ }^{137}$

132. See id. I 164. The other patently religious closed-days were omitted from the interim and final Constitutions.

133. See SOUTH AFRICA YEARBOOK 2000/01, supra note 16.

134. See S v. Solberg, 1997 (10) BCLR 1348 (CC). TI 164, 176.

135. See id. 9133 (O'Regan, dissenting), citing $\$ 98(5)$ of the interim Constitution.

136. See id. $\mathbf{9} 116$.

137. See id. $91120-21$. 
Foremost among the dissenters' concerns was the ability of the State to pressure religious minorities into observing officially sanctioned religious activity: "When the power, prestige and financial support of the govemment is placed behind a particular religious belief, the indirect coercive pressure upon religious minorities to conform to the prevailing officially approved religion is plain." ${ }^{138}$ Specifically, the dissent was bothered by the possibility that government power was being used to promote one religion over others and, in so doing, coerce religious minorities into conforming to the prevailing norms promoted by the State. By taking this approach the dissent, in effect, merged together its freedom of exercise and establishment analyses.

The dissent also noted that Sundays were chosen as closed days alongside other plainly religious holidays. Justice $O^{\prime}$ Regan argued that there was a strong likelihood, then, that religious favoritism informed this choice, giving a "legislative endorsement to Christianity, but not to other religions." 139 The religious purpose of the statute seemed even stronger when the dissent recalled that ten other secular holidays were not included as closed-days. ${ }^{140}$

The dissent was also troubled by the law's existence after the fall of the old regime. This was especially true, in its view, given the preamble's proclamation that democracy, freedom, and human dignity would govern the new South Africa with a view toward rectifying past social injustices. ${ }^{141}$ In the dissent's opinion, legislation associated with the most objectionable practices of the old order would, per se, violate this proclamation. Accordingly, the Liquor Act constituted an infringement on appellant's Section 14 rights.

Having established that an initial infringement had occurred, the dissent applied a limitations analysis under Section 33 to determine if this infringement was dispositive. ${ }^{142}$ Section 33 permitted government limitation of fundamental rights only if such restrictions were reasonable, justifiable, and, most importantly, necessary. In defining the boundaries of that inquiry, the dissent adopted the approach used in S. v. Makwanyane, ${ }^{143}$ in which the Court held that legislation limiting fundamental rights was necessary if and only if it was accomplished by the least restrictive means available. ${ }^{144}$

In applying this standard, the dissent was troubled by the lack of evidence regarding the exact purpose the State hoped to achieve by enforcing

138. Id. I 120, quoting Engel v. Vitale, 370 U.S. 421 (1962); see supra note 62, for a discussion of how Justice O'Regan's efforts to read "establishment protections" into Section 14 allowed her access to American Supreme Court establishment decisions that seem somewhat out of place in the South African context.

139. S v. Solberg, 1997 (10) BCLR 1348 (CC), 9125.

140. See id.

141. See van der Vyver, State-Sponsored Proselytization, supra note 14, at 825.

142. See S v. Solberg, 1997 (10) BCLR 1348 (CC), 9130.

143. See S v. Makwanyane, 1995 (6) BCLR 665 (CC).

144. See id. The Makwanyane Court stated, "it will need to be shown that the ends sought by the legislation cannot be achieved sufficiently and realistically by other means which would be less destructive of entrenched rights." S v. Solberg, 1997 (10) BCLR 1348 (CC), 130. 
the legislation. ${ }^{145}$ This vacuum caused the dissent to engage in speculation as to the purpose of the law, which it ultimately accepted as being a restriction on the sale of alcohol to curb public consumption..$^{146}$ However, given the holes that existed in such an approach to curbing consumption - namely, that consumption itself was not prohibited and that alcohol was still sold on other public holidays - the dissent was not impressed with the necessity or effectiveness of the means used by the State to achieve its desired end. ${ }^{147}$ When considered against the backdrop of the religious importance of the selected closed-days, the legitimacy of the State's means became slighter still. ${ }^{148}$

Having failed the dissent's balancing test, the Liquor Act was declared unconstitutional to the extent that it prohibited sale of alcohol on closed-days associated only with Christianity. ${ }^{149}$

While the dissent correctly concluded that the State was unjustified in limiting appellant's fundamental right to freedom of religion, its conclusion is flawed because it conducted its evaluation on the basis of Section 14. Section 14 prohibits religious observances only when the observances are conducted on an inequitable basis, or there is coercion, and the activity takes place at a state institution. ${ }^{150}$ While it is likely that the Act benefited and paid tribute to Christianity, this was not a case involving violations that occurred at a state institution. Nor was there any evidence of coercion. As such, the dissent's reliance on Section 14's inequity analysis is misplaced.

Section 8 provided a much better platform on which to view this law. Under Section 8, all citizens are to be treated equally and "unfair discrimination" by the State based on religion is grounds for striking down a statute, irrespective of the involvement of a state institution. Section 8 also provided for a lower threshold for proving a violation of unequal treatment than does Section 14, as it permitted a case to be built on indirect discrimination. ${ }^{151}$

While the appellant did not demonstrate a strong case of direct State discrimination against her, there was enough evidence in the record to permit the Justices to decide that the law, in an indirect way, placed non-Christians

145. See S v. Solberg, 1997 (10) BCLR 1348 (CC), I 130. Justice O'Regan stated that the lack of such evidence on the part of the state inevitably makes it much more difficult to justify the infringement. See id. Note how this comment demonstrates a view of legislative interpretation that is diametrically opposed to the solicitous view afforded the State's reasoning by Justice Sachs.

146. See id. 9 132. The dissent did not adopt the view that the Act intended to create a common day of rest for all South Africans, as it did not require shops to shut down on that day. See id. 1131 .

147. See id. $\mathbb{1} 132$.

148. See id.

149. See id. 9133.

150. See Inter. Const. $\$ 8$.

151. See id. 
at an unfair disadvantage. Under a Section 8 analysis, the infringement caused by the law would only be permissible if it satisfied Section 33's limitation requirements. ${ }^{152}$ Under Section 33, the law in question must be "reasonable, justifiable and necessary."153 As previously noted, there are less restrictive means available to accomplish the State's secular aims. ${ }^{154}$ Therefore, the legislation, as written, is not "necessary."155 However, for all the dissent's efforts to incorporate American establishment jurisprudence into its ratio decidendi, it failed to avail itself of the one section that offered the most natural and indigenous resolution to the problem under consideration. ${ }^{156}$

\section{SUMMARY AND CONCLUSION}

State v. Lawrence unfortunately did not produce a clear precedent. Partially as a result of appellant's use of religious defenses as a last resort to her criminal conviction the Court was forced into a middling set of opinions. Often the factions split along philosophical lines, using constitutional provisions as shorthand for their own policy beliefs.

The plurality held that there was no establishment clause in the South African Constitution but that appellant's correct avenue of challenging the law lay in Section 8's Unfair Discrimination clause. The plurality chose not to conduct this review. However, the plurality remained faithful to the idea that South Africa was the product of a unique historical experience that mandated an approach to constitutional jurisprudence that differed in significant ways from other well-known legal traditions. ${ }^{157}$

The concurrence held that there was an establishment clause in the Constitution and that it was violated by the Act. However, it held the violation was permissible since the State's secular interest in keeping the law was reasonable and "necessary." This conclusion resulted from a balancing test where the secular purposes proffered for the legislation were weighed against the harm done to appellant's religious rights without regard to the efficacy of the State's means in achieving the desired aim. In coming to this conclusion, the concurrence meandered along a tortured analysis of Section 14.

The dissent stated that there was no establishment clause in the Constitution, then proceded to find one. ${ }^{158}$ Moreover, the dissenters seemed

152. See supra note 123.

153. S. AFr. CONST. ch. $2, \S 33$.

154. See supra note 135 and accompanying text.

155. See id.

156. See S v. Solberg, 1997 (10) BCLR 1348 (CC), I 129, where O'Regan J states, "It is not necessary, in view of my conclusion, to consider whether section 90 would constitute a breach of that constitutional provision [\$ 8] as well; see also supra note 63, at 353-54.

157. See Christof Heyns \& Danie Brand, The Constitutional Protection of Religious Human Rights in Southern Africa, 14 EMORY INT'L L. REV. 699, 759 n.147 (2000).

158. See Gouws \& du Plessis, supra note 16, at 681 , where the authors indicate that although there was a majority of justices (6/9) voting to dismiss appellant's claim, another 
intent on making public policy fit inside a constitutional box that would not warmly receive it. More than the concurrence, the dissent sweepingly incorporated American establishment clause theory into its holding, even when such an approach strained the credible meaning of the sections under consideration. At the same time, an adequate section existed in the South African Constitution that could have accomplished the same result. Outside of this anomaly, however, the dissent adhered more loyally to the spirit of the new Constitution than did the other factions.

The religious interpretation of the Liquor Act is uncertain after this decision. Looking at the holdings, it is apparent that those factions that agreed with each other on the outcome of the case fundamentally disagreed on how to get there. Conversely, those factions that disagreed most strongly on the outcome of the holding substantially agreed on the means to reach it. In fact, there was no outright majority of the Court on any one, single, legal issue. ${ }^{159}$

Perhaps the Court, presented with an unattractive set of facts, decided to defer making clear precedent until a stronger case came along. But the Court had the right to refuse this case which, on reflection, it might better have done. ${ }^{160}$ The fractionalized outcome of the Court portends mediocre justice in similar future controversies. Part of this confusion originates in the language of the Constitution itself. In its attempt to be precise, the legislature created a situation where the overarching meaning of its constitutional provisions was buried in a haze of details. As the Court tried to separate what was principle from what served as example, larger issues of public policy became obscured by minutiae.

Instead of further clouding the issues in future cases, the Court should defer all rulings until the legislature clarifies its stance on such critical issues as establishment, the scope of equality, and the application of the preambular language that, remarkably enough, seems to be the clearest language of all.

majority (5/9) held that there was an establishment clause in Section 14. See also supra note 113 , at 755; but see infra note 159.

159. See Christof Heyns, Proselytism in Southern Africa (April 1997) (unpublished manuscript on file with Johan van der Vyver at Emory University School of Law). The author argues that since no majority was reached on any single legal issue, the case itself serves as but shaky precedential value. See id.

160. See Gouws \& du Plessis, supra note 16, at 681. 
